\title{
JUURNAL.RU
}

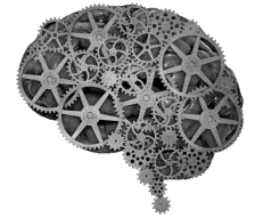

COMPANY GROUP "INTELLEKT"

\author{
Воробьева О.В., Любовцева Л.А. \\ Чувашский государственный университет им. И.Н. Ульянова \\ Чебоксары, Россия
}

doi: 10.18411/lj2016-6-1-05

\section{Сравнительное люминесцентно-гистохимическое исследование нейроаминов в структурах костного мозга при гетеротрансплантации костного мозга}

Применение люминесцентно-гистохимических методов позволило ряду исследователей выявить и изучить биоаминосодержащие структуры костного мозга, которые участвуют в регуляции процессов иммуногенеза [1]. Как известно, регуляция многих органов происходит при помощи особых биоаминсодержащих структур, в состав которых входят тучные (ТК) и гранулярные люминесцирующие клетки (ГЛК) [2,3]. Выявлено, что в гранулах этих клеток содержатся катехоламины (КА), серотонин (СТ). ГЛК совместно с ТК являются клетками-регуляторами и участвуют в автономной регуляции иммунологических и кроветворных органов.

Цель исследования - изучение влияния гетеропересадки костного мозга на распределение биогенных аминов между биоаминосодержащими структурами костного мозга.

Материал и методы исследования: Экспериментальные исследования проведены на 30 мышах, 1 группа -интактные мыши $(\mathrm{n}=15) .2$ группе производили гетеротрансплантацию костного мозга $(\mathrm{n}=15)$. Под эфирным наркозом брали из бедренной кости 0,1 мл костного мозга кошки помещали в 1 мл физиологического раствора и тщательно размешивали. 1 мл суспензии костного мозга вводили в хвостовую вену мышам. 
Методы исследования: 1. Люминесцентно - гистохимический метод [8] для выявления гистамина. 2. Для избирательного выявления КА и СТ применялся люминесцентно - гистохимический метод Фалька-Хилларпа. 3. Количественно уровень КА, СТ и гистамина в структурах оценивались с помощью цитоспектрофлуориметрии. 4. Представление о количественном распределении тучных клеток и ГЛК дает метод подсчета их в 5 полях зрения микроскопа при увеличении об. 40 ок. 10.

\section{Результаты исследования и обсуждение}

Через 15 минут увеличивается выявляемость нервных волокон, число ГЛК снижено, однако содержание КА в них повышено. Число ТК уменьшается в 1,9 раза по сравнению с интактными мышами. МКЦ имеют расплывчатые очертания, в связи с образованием тромбоцитов.

Через 40 мин после гетеропересадки в КМ выявляется повышенное число ГЛК, ТК с увеличенным содержанием КА и СТ в них по сравнению с интактными мышами. Появляются КА в цитоплазме нейтрофилов и моноцитов.

Через 1 сутки число ГЛК и ТК имеет тенденцию к снижению, а в них уменьшается содержание КА и СТ. ТК начинают определяться около липоцитов. Они мелкие, зеленые, число их снижено (Таблица 1).

Показатели интенсивности люминесиениии КА в клетках КМ мышей

Таблица 1 после гетеропересадки КМ (усл.ед.)

\begin{tabular}{|c|c|c|c|c|c|c|c|}
\hline \multirow{2}{*}{ Название клеток } & \multicolumn{7}{|c|}{ Время введения } \\
\cline { 1 - 9 } & Без введения & 15 мин & 40 мин & 60 мин & 4 часа & 1 сутки & 2 сутки \\
\hline Число ГЛК & 15,6 & $\mathbf{2 8 , 1}$ & $\mathbf{1 9 , 2}$ & $\mathbf{3 8 , 3}$ & $\begin{array}{c}54,2 \\
\text { Единич }\end{array}$ & 5,2 & нет \\
\hline Число ТК & 19,6 & 57,2 & $\mathbf{2 0 , 6}$ & $\mathbf{4 8 , 5}$ & $\mathbf{2 9 , 6}$ & 7,4 & Гранулы \\
\hline МКЦ & - & - & - & 10,6 & 28,2 & 17,3 & 13,2 \\
\hline
\end{tabular}

Примечание: * - достоверность отличий рассчитана по отношению к данным интактных крыс, p < O,O5.

Выявляются мелкие клетки с бобовидным ядром, имеющие одинаковую зернистость. Появляется новая генерация макрофагов, располагающихся в основном вокруг жировых клеток. АПУД- клеток очень мало, до 4,1 на весь препарат. Постепенно образуется белая жировая ткань, в которой накапливаются КА и СТ. Около гемопоэтических островков размножения и липоцитов обнаруживаются отдельные фрагменты нервных волокон. 
Через 60 мин содержание КА и СТ в ГЛК увеличивается в 2,5 раза. Повышается содержание КА в ТК. Выявляемость адренергических нервных волокон остается повышенной. Они определяются по ходу сосудов, около гемопоэтических островков размножения, внутри которых расположены моноаминоциты.

Через 4 часа - ГЛК - единичны, содержание СТ в них понижено, однако количество КА остается выше нормы. Продолжают определяться нейтрофилы с повышенным содержанием в них СТ. Число гемопоэтических островков остается повышенным, но число митотически делящихся в них клеток снижается вдвое. Во всех островках размножения полностью разрушается контактность между клетками продуцентами. Увеличивается выявляемость МКЦ.

Впервые выявляются моноциты, которые в отличие от дендритных макрофагов имеют округлую форму, небольшие размеры и единичные слабо люминесцирующие гранулы. В увеличенных в размерах банальных макрофагах обнаруживаются частицы структур, содержащие серотонин. По размеру они подходят или к тромбоцитам, или хиломикронам.

Через 2-е суток люминесцируют лишь единичные гранулы в ГЛК, с уменьшенным содержанием в них нейроаминов. Нервные волокна определяются в виде отдельных фрагментов в основном около групп жировых клеток.

Выявляется перерождение костного мозга на жировую ткань, около которой концентрируются измененные ТК, со сниженным содержанием нейроаминов. Нервные волокна определяются в виде отдельных фрагментов, в основном около групп жировых клеток.

Таким образом, при подсадке чужеродного костного мозга резко снижается число аминосодержащих клеток. Происходит распад ТК. Однако, образуются жировые клетки, поддерживаемые вновь образующимися ГЛК и ТК, с повышенным в них содержанием аминов. Этот факт еще раз подтверждает 
способность ГЛК и ТК регулировать процессы репарации (восстановления) клеток при помощи нейроаминов.

\section{Выводы:}

1. После гетеропересадки развивается постепенная супрессия синтеза нейроаминов в аминосодержащих структурах, истощение депо биогенных аминов и накоплением их в липоцитах.

2. Происходит выброс и опустошение клеток от нейроаминов, приводящий к изменению дифференцировки клеток в костном мозге.

3. Происходит опустошение собственных клеток костного мозга от нейроаминов с последующим жировым перерождение костного мозга. Происходит гибель клеток -продуцентов нейроаминов в костном мозге.

\section{Литература:}

1. Гривцова Л.Ю., Тупицын Н.Н. Субпопуляции трасплантируемых стволовых кроветворных клеток. Онкогематология. -2006.- Т. 8, №1.- С. 65-71.

2. Карноухов Н.А. Люминесцентные параметры ядерных клеток крови в процессе иммунного ответа организма. Биофизика. -1984.- №2.- С. 276279.

3. Любовцева Л. А., Любовцева Е.В. Биоаминсодержащие структуры костного мозга при системных заболеваниях крови. Морфология. -2012.№3.- C. 95-96. 